\title{
Article \\ Comparison of Fracture Strengths of Three Provisional Prosthodontic CAD/CAM Materials: Laboratory Fatigue Tests
}

\author{
José Manuel Mendes ${ }^{1, * \mathbb{D}}$, Pedro Colaço Botelho ${ }^{2} \mathbb{D}$, Joana Mendes ${ }^{2}$, Pedro Barreiros ${ }^{2} \mathbb{D}$, Carlos Aroso $^{2}(\mathbb{D})$ and \\ António Sérgio Silva ${ }^{1}$
}

check for

updates

Citation: Mendes, J.M.; Botelho, P.C.; Mendes, J.; Barreiros, P.; Aroso, C.; Silva, A.S. Comparison of Fracture Strengths of Three Provisional Prosthodontic CAD/CAM Materials: Laboratory Fatigue Tests. Appl. Sci. 2021, 11, 9589. https://doi.org/ 10.3390/app11209589

Academic Editors: Gabriele Cervino and Bruno Chrcanovic

Received: 12 September 2021

Accepted: 12 October 2021

Published: 14 October 2021

Publisher's Note: MDPI stays neutral with regard to jurisdictional claims in published maps and institutional affiliations.

Copyright: (c) 2021 by the authors. Licensee MDPI, Basel, Switzerland. This article is an open access article distributed under the terms and conditions of the Creative Commons Attribution (CC BY) license (https:/ / creativecommons.org/licenses/by/ $4.0 /)$.
1 Dental Science Department, Instituto de Investigação e Formação Avançada em Ciências e Tecnologias da Saúde (IINFACTS), Rua Central da Gandra 1317, 4585-116 Gandra, Portugal; asergio.silva@iucs.cespu.pt

2 Department of Oral Rehabilitation, Instituto Universitário de Ciências da Saúde, Rua Central da Gandra 1317, 4585-116 Gandra, Portugal; pedrocolacobotelho@gmail.com (P.C.B.); janamendes_9@hotmail.com (J.M.); jose.fonseca@iucs.cespu.pt (P.B.); carlos.ribeiro@iucs.cespu.pt (C.A.)

* Correspondence: jose.mendes@iucs.cespu.pt; Tel.: +351-224-157-100

\begin{abstract}
Temporary restorations play a fundamental role in oral rehabilitation. They can be used on teeth or implants for a variable period of time during the period prior to rehabilitation with definitive restorations. Temporary or provisional restorations manufactured via CAD/CAM methods are becoming increasingly used in the intermediate phase of the treatment of complex cases. The main objective of this study was to compare the fracture resistance of three materials used in the creation of provisional crowns on implants: polymethyl methacrylate (PMMA), composite resin, and polyether ether ketone (PEEK). Fracture resistance in PMMA (Zirkonzahn Temp Basic ${ }^{\circledR}$, Gais, South Tyrol, Italy) ranged from $1216.0 \mathrm{~N}$ to $1461.2 \mathrm{~N}$, with a mean of $1300.4 \mathrm{~N}(\mathrm{SD}=97.09)$. In the composite material (3M Lava Ultimate ${ }^{\circledR}$, St. Paul, MN, USA), fracture resistance varied between 1343.5 N and 1490.6 N, with a mean of $1425.9 \mathrm{~N}(\mathrm{SD}=49.03)$. Lastly, in PEEK (Tecno Med Mineral ${ }^{\circledR}$, Zirkonzahn ${ }^{\circledR}$, Gais, South Tyrol, Italy), fracture resistance ranged from $2294.8 \mathrm{~N}$ to $2451.7 \mathrm{~N}$, with a mean of $2359.5(\mathrm{SD}=50.01)$. The crowns made with the PEEK Tecno Med Mineral ${ }^{\circledR}\left(\right.$ Zirkonzahn $^{\circledR}$, Tyrol, Italy) material presented the best fracture resistance, followed by the crowns made with the Lava Ultimate $^{\circledR}\left(3 \mathrm{M}^{\circledR}\right.$ ESPE, Minnesota, USA) composite resin material and, finally, those made with the PMMA Temp Basic ${ }^{\circledR}$ (Zirkonzahn ${ }^{\circledR}$, Tyrol, Italy) material.
\end{abstract}

Keywords: provisional restorations; fracture resistance; PMMA; composite resin; PEEK

\section{Introduction}

Temporary restorations play a fundamental role in oral rehabilitation. They can be used over teeth or over implants for a variable amount of time during the period prior to rehabilitation with permanent restorations [1-4].

Implant-supported provisional restorations (ISPRs) are fundamental to enhancing the esthetics, contour, and modeling of peri-implant tissue architecture. Proussaefs [5] suggested the term "guided tissue healing" to describe the use of an ISPR to guide the soft tissue architecture. This approach constitutes the state of the art in implantology $[2,3,6,7]$.

Temporary crowns can be made of polymethyl methacrylate (PMMA), composite resin, or polyether ether ketone (PEEK). These provide strength, dimensional and marginal stability, and functional occlusal load $[2,3,6]$.

The demand for restorations which are as similar as possible to natural teeth has increased in recent years due to improvements in techniques and materials, as well as the evolution of patient expectations $[2,3]$.

PMMA and composite resin are the most commonly used materials in the creation of temporary fixed dental prostheses. Traditionally, PMMA is presented as a solute and solvent, and its polymerization process is chemical. The advantages of this type of material are good marginal fit with good transverse strength, providing a durable restoration [2]. 
The material has good polishability, but its abrasion resistance is low, and patients who exhibit parafunctional habits may show wear of the material over time [2,3]. Additional disadvantages include a high volumetric shrinkage during setting, with a high exothermic reaction; the degree of heat generated by the exothermic reaction is related to the volume of material being cured [5]. When this may be an issue either because of pulpal health or patient comfort, fabricating the majority of the provisional restoration extraorally on a model and relining intraorally will reduce the volume of material being cured on the teeth and lower the heat generated during the exothermic setting [6,7]. As another consideration with regard to the pulp, it has been shown that free monomer may be toxic to the pulp and this material may not be the material of choice when pulpal health is questionable or when the material will be in close approximation to the pulp [8]. Furthermore, these materials may be objectionable to the patient because of odor, and there have been some reported tissue reactions to the monomer [9].

Composite resins are typically presented in a self-mixing paste/paste form, with chemical or dual polymerization. Typically, the composite resins are reinforced to a provisional polymer matrix reinforced with fibers. The fibers are usually glass, carbon, or aramid. Most composites have strong, stiff fibers in a matrix which is weaker and less stiff. The objective is usually to make a component which is strong and stiff, often with a low density. Commercial material commonly has glass or carbon fibers in matrices based on thermosetting polymers, such as epoxy or polyester resins. Sometimes, thermoplastic polymers may be preferred $[6,7]$.

In addition to these forms, PMMA and composite resin are also available in CAD/CAM (computer-aided design/computer-aided manufacturing) blocks, with PEEK available only in this form $[1,2,4]$.

CAD/CAM blocks are manufactured under controlled industrial conditions involving high temperatures and pressures, resulting in better conversion and a decrease in residual monomers. In this process, the physical properties of the materials are improved compared to those formed with the use of traditional methods, allowing for the use of CAD/CAM systems in the intermediate phase of the treatment of complex cases (e.g., involving adjustment of the occlusal plane). On the other hand, the high monomer conversion rate decreases the adhesion capacity of adhesive resins $[1,6,7]$.

There also exist CAD/CAM blocks manufactured with an interface that helps cementation on a titanium base, allowing for the fabrication of temporary restorations screwed to the implant, thus making maintenance easier. This interface allows for optimal adaptation of the crown and prevents excess cement usage, which can lead to inflammatory reactions and bone loss [6].

PEEK is a recent material in dentistry. It has mechanical properties similar to those of dentin and enamel, including a high resistance to fracture; however, it is fragile in its homogeneous form. For this reason, it is usually combined with carbon or ceramic fibers [8-11]. It is a semicrystalline, high-performance engineering thermoplastic. PEEK exhibits exceptional tensile properties. When reinforced with carbon fibers, a tensile strength of $29,000 \mathrm{psi}$ can be achieved with excellent properties retained at $299^{\circ} \mathrm{C}$. The polymer also exhibits excellent creep resistance. When combined with flexural and tensile characteristics, it provides an excellent balance of properties where the material is required to withstand high loadings for long periods at high temperature without permanent deformations. Its flexural modulus at very high temperatures can further be improved with glass or carbon reinforcement. Reinforcement also increases creep and fatigue resistance, thermal conductivity of the polymer, and heat distortion temperature [8-11].

Several studies have shown that the most common cause of failure is fracture of temporary restorations, leading to discomfort, pain, and economic losses. Thus, fracture resistance is essential and should be considered when choosing the material for these applications $[1,2,7]$. 
The aim of this study was to evaluate and compare the fracture resistance of three materials used in the creation of temporary crowns on dental implants: PMMA, composite resin, and PEEK.

\section{Materials and Methods}

\subsection{Sample Characteristics}

A total of 45 temporary crowns of the following types were tested: PMMA (Temp Basic $^{\circledR}$, ZIRKONZAHN $^{\circledR}$, Gais, South Tyrol, Italy), composite resin (3M Lava Ultimate ${ }^{\circledR}$, St. Paul, MN, USA), and PEEK (Tecno Med Mineral ${ }^{\circledR}$, ZIRKONZAHN ${ }^{\circledR}$, Gais, South Tyrol, Italy). This study was carried out using 45 laboratory analogues, 45 prosthetic abutments, and 15 temporary crowns for each brand tested, as detailed in Table 1. The brand of all implant parts was MIS implants technologies ${ }^{\circledR}$ (Dentsply Sirona ${ }^{\circledR}$, Ahihud, Israel).

Table 1. Sample characterization.

\begin{tabular}{|c|c|c|c|}
\hline Group & Material & Brand & Quantity \\
\hline A & PMMA & $\begin{array}{c}\text { Temp Basic }{ }^{\circledR} \\
\text { (Item number: TMAA1716) }\end{array}$ & 15 \\
\hline $\mathrm{B}$ & Composite Resin & $\begin{array}{c}\text { Lava Ultimate }{ }^{\circledR} \\
\text { (Item number: 70-2010-8522-5) }\end{array}$ & 15 \\
\hline C & PEEK & $\begin{array}{c}\text { Tecno Med Mineral } \\
{ }^{\circledR} \\
\text { (Item number: TMAK0112) }\end{array}$ & 15 \\
\hline
\end{tabular}

\subsection{Data Collection}

A standard laboratory protocol was established and applied at the Institute for Research and Advanced Training in Health Sciences and Technologies (IINFACTS-CESPU) in order to test all selected samples.

Model fabrication was conducted as follows:

1. Preparation for the experimental phase began with the preparation of 45 samples: 15 temporary PMMA crowns, 15 temporary composite resin crowns, and 15 temporary PEEK crowns, as shown in Figure 1. All temporary crowns were numbered and cataloged for later identification.

2. Temporary crowns were analyzed using a stereoscope (Olympus ${ }^{\circledR}$ SZ61-Tokyo, Japan) and a $90 \times$ magnifying glass in order to ensure the absence of cracks or defects.

3. Each antirotational titanium provisional abutment was screwed onto a laboratory analogue (Figure 2a). The 45 temporary crowns were cemented onto the antirotational titanium temporary abutments with the cement Rely $X^{\circledR}$ Unicem 2 Automix $\left(3 \mathrm{M}^{\circledR}\right.$, Minnesota, USA), with a waiting time of $6 \mathrm{~min}$ allowed in order to ensure complete fixation. The cement was automix, respecting the manufacturer's instructions. The crowns were filled and cemented to the temporary abutment and stored. These components were then adapted to the load cell fixation table (Figure 2b).

4. The resistance of the crowns was tested using a CS ${ }^{\circledR}$ Dental Testing Machine (Barcelona, Spain), as shown in Figure 3a. The $\mathrm{CS}^{\circledR}$ Dental Testing Machine is a fatigue testing device built in accordance with 2006/42/EC machine safety and EN 12100-1/2, EN 954-1, EN 1037, EN 61310-1/2, EN 60204-1, EN ISO 14121-1, and EN ISO 13850 standards.

5. A piston was activated to transmit a compressive force (at a speed of $1 \mathrm{~mm}$ per minute) until fracturing occurred in all PMMA, composite resin, and PEEK crowns, as shown in Figure $3 b$. The piston was placed in the middle of the occlusal plane between the buccal and palatal cusps. A rubber sheet was placed to serve as a buffer between each of the sample cores and the piston, in order to remove any buildup of stress during the application of force.

6. An Excel CS ${ }^{\circledR}$ Dental Testing Machine file was stored on a computer for further graphic and value analysis. 


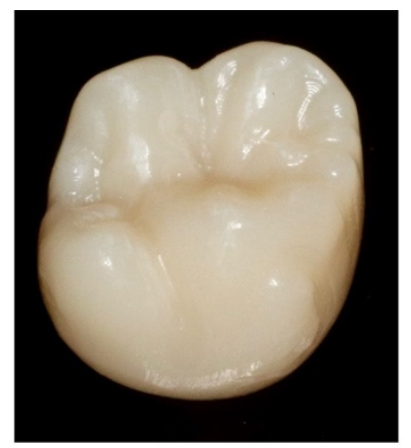

(a)

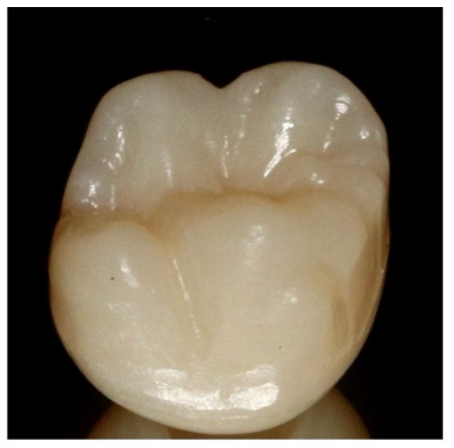

(b)

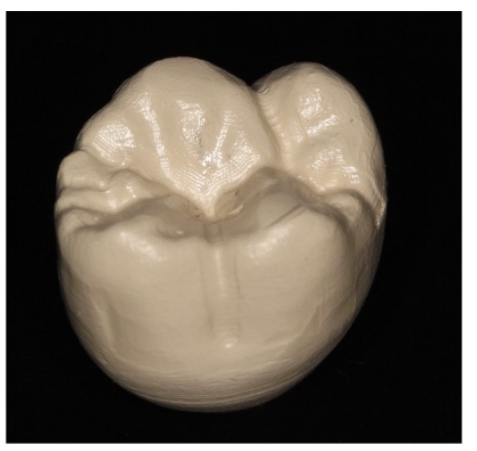

(c)

Figure 1. Temporary crowns in CAD/CAM: (a) PMMA (Temp Basic $\left.{ }^{\circledR}\right)$, (b) composite resin (Lava Ultimate $\left.{ }^{\circledR}\right)$, and (c) PEEK $\left(\right.$ Tecno Med Mineral ${ }^{\circledR}$ ).

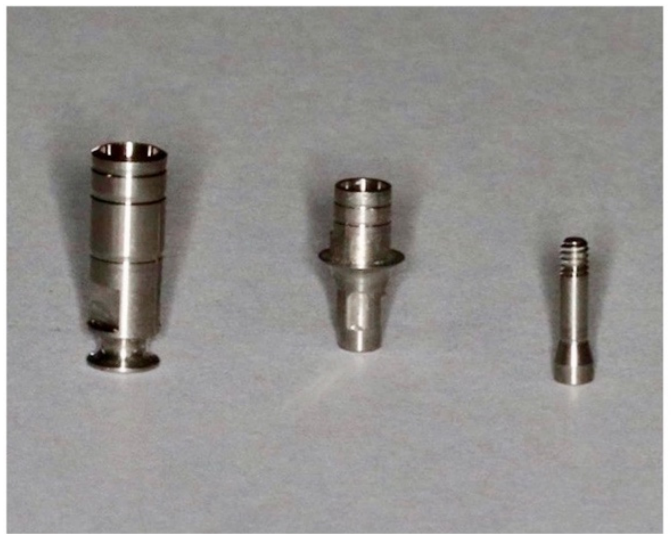

(a)

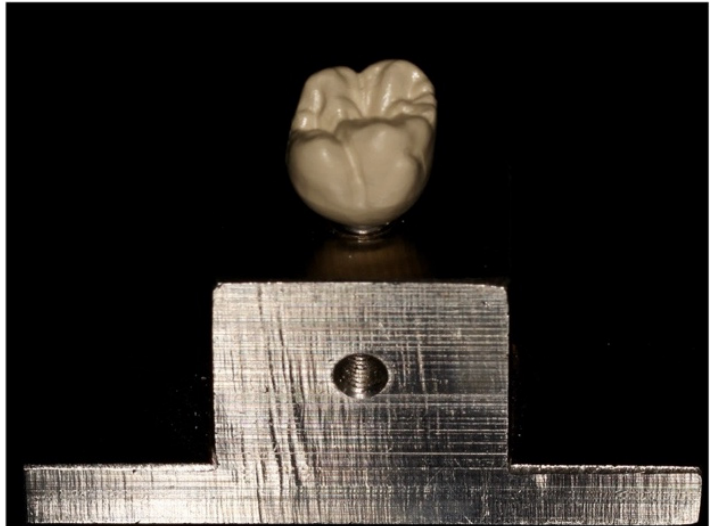

(b)

Figure 2. (a) Antirotational titanium temporary abutment, laboratory analogue, and screw; (b) CAD/CAM crown adapted to the load cell clamping table.

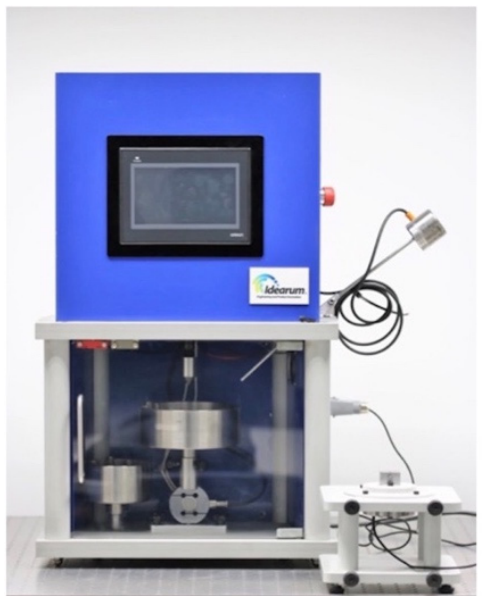

(a)

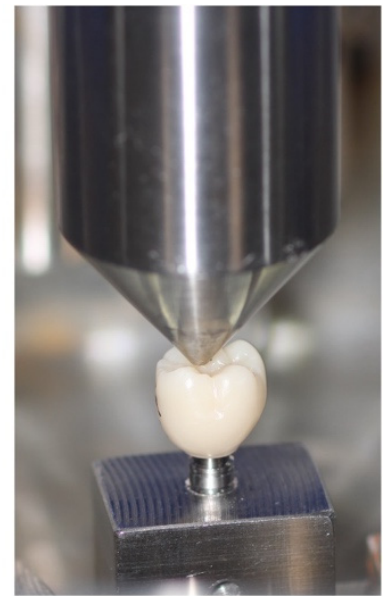

(b)

Figure 3. (a) $\mathrm{CS}^{\circledR}$ Dental Testing Machine; (b) simulated compressive force movement.

The types of fracture were also evaluated according to Burke's classification across the entire sample, as described in Table 2. 
Table 2. Burke's classification.

\begin{tabular}{cc}
\hline Fracture Type & Description \\
\hline I & Intact crown \\
II & Crack \\
III & Less than half of crown lost \\
IV & Crown broken in midline, half of crown lost or out of position \\
V & More than half of the crown lost \\
\hline
\end{tabular}

\subsection{Statistical Analysis}

Data were analyzed with SPSS, version 22. Descriptive statistics were presented as means $(\mathrm{M})$ and standard deviations (SD) for fracture resistance in newtons $(\mathrm{N})$, after assessing variable symmetry with the symmetry coefficient $(<|1|)$ and histograms.

Normality was assessed using the Shapiro-Wilk test. Variance homogeneity was assessed using Levene's test (Field, 2003). After confirming both assumptions, parametric tests were used to answer research goals.

The association of type of fracture with type of material was assessed using the chi-square exact test $\left(\chi^{2}\right)$.

The association of fracture resistance with type of material and type of fracture was assessed using unifactorial ANOVA. Multiple comparisons were performed using Tukey tests. Effect size was assessed using the eta ${ }^{2}\left(\eta^{2}\right)$ test, considering the following thresholds: 0.01 for a low, 0.06 for a moderate, and 0.14 for a high size effect.

The $t$-test was used to compare fracture resistance with the thresholds of $300.8 \mathrm{~N}$ and $966.94 \mathrm{~N}$.

The maximum level of significance considered was $5 \%$.

\section{Results}

Forty-five samples were assessed, 15 of each material, PMMA-Temp Basic ${ }^{\circledR}$, composite resin-Lava Ultimate ${ }^{\circledR}$, and PEEK-Tecno Med Mineral ${ }^{\circledR}$, with the objective of testing the fracture resistance expressed in newtons $(\mathrm{N})$. Figure 4 shows the distribution of all fracture resistance measurements.

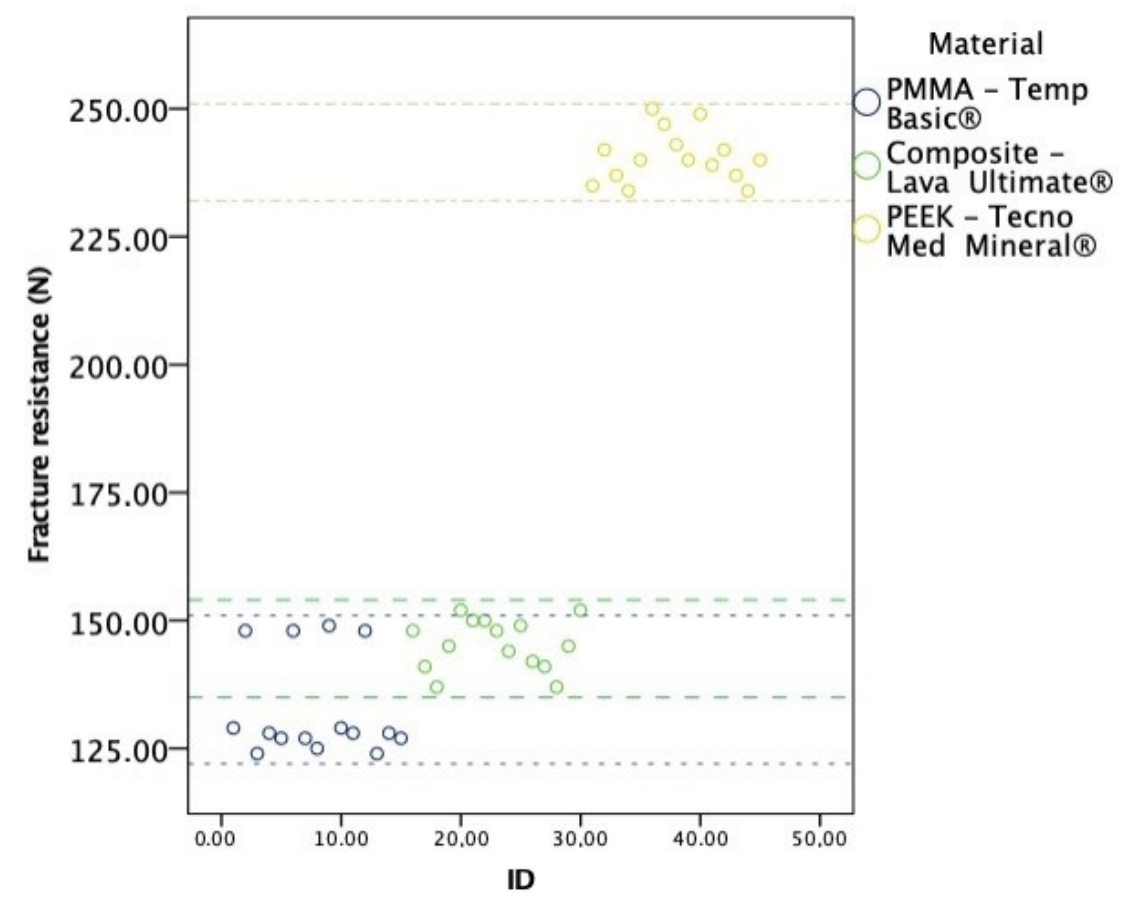

Figure 4. Distribution of all fracture strength $(\mathrm{N})$ measurements. 
Fracture resistance in PMMA (Temp Basic ${ }^{\circledR}$ material) ranged from $1216.0 \mathrm{~N}$ to $1461.2 \mathrm{~N}$, with a mean of $1300.4 \mathrm{~N}(\mathrm{SD}=97.09)$. In the composite material (Lava Ultimate $\left.{ }^{\circledR}\right)$, fracture resistance varied between $1343.5 \mathrm{~N}$ and $1490.6 \mathrm{~N}$, with a mean of $1425.9 \mathrm{~N}(\mathrm{SD}=49.03)$. Lastly, in the PEEK (Tecno Med Mineral ${ }^{\circledR}$ material), fracture resistance ranged from $2294.8 \mathrm{~N}$ to $2451.7 \mathrm{~N}$, with a mean of $2359.5(\mathrm{SD}=50.01)$. ANOVA tests detected statistically significant differences among the types of material included in this study, $\mathrm{F}_{(2,42)}=1056.2$, $p<0.001, \eta^{2}=0.98$, with a high effect size. Tukey tests detected statistically significant differences among all material types, with higher resistance in the PEEK material type, followed by the composite and finally PMMA (Table 3).

Table 3. Comparison of fracture resistance by material type.

\begin{tabular}{|c|c|c|c|c|c|}
\hline & Minimum & Maximum & $\mathbf{M}$ & SD & ANOVA \\
\hline PMMA-Temp Basic ${ }^{\circledR}$ & 1216.02 & 1461.19 & 1300.36 & 97.09 & $\mathrm{~F}_{(2 \cdot 12)}=364.2$ \\
\hline Composite Resin-Lava Ultimate ${ }^{\circledR}$ & 1343.51 & 1490.61 & 1425.89 & 49.03 & $p<0.001$ \\
\hline PEEK-Tecno Med Mineral ${ }^{\circledR}$ & 2294.76 & 2451.66 & 2359.48 & 50.01 & $\eta^{2}=0.98$ \\
\hline
\end{tabular}

Note: Tukey test showed significant differences among all types of material: PMMA vs. composite $(p=0.021)$ PMMA vs. PEEK $(p<0.001)$; composite vs. PEEK $(p<0.001)$.

Statistically significant results were also found in the comparison by type of fracture, $\mathrm{F}_{(2,44)}=1467.0, p<0.001, \eta^{2}=0.99$, with higher resistance values in type III $(\mathrm{M}=2359.5$; $\mathrm{SD}=50.0)$, followed by type $\mathrm{V}(\mathrm{M}=1434.7 ; \mathrm{SD}=49.0)$ and type $\mathrm{IV}(\mathrm{M}=1281.7 ; \mathrm{SD}=75.5)$. Tukey tests showed significant differences among all types of fracture (Table 4).

Table 4. Comparison of fracture strength by fracture type.

\begin{tabular}{cccccc}
\hline & Minimum & Maximum & M & SD & ANOVA \\
\hline Type III & 2294.0 & 2451.7 & 2359.5 & 50.0 & $\mathrm{~F}_{(2 \cdot 12)}=1467.0$ \\
Type IV & 1216.0 & 1422.0 & 1281.7 & 75.5 & $p<0.001$ \\
Type V & 1343.5 & 1490.6 & 1434.7 & 49.0 & $\eta^{2}=0.99$ \\
\hline
\end{tabular}

Note: Tukey test showed significant differences among all types of fractures III vs. IV ( $p<0.001)$; III vs. V $(p<0.001)$; IV vs. V $(p=0.008)$.

The type of material was associated with the type of fracture $(p<0.001)$. Type III fracture was exclusive to the PEEK Tecno Med Mineral ${ }^{\circledR}(100 \%)$, type IV fracture was associated with the PMMA Temp Basic ${ }^{\circledR}$ material $(78.6 \%)$, and type V fracture was associated with the Lava Ultimate ${ }^{\circledR}$ composite material with $75 \%$ prevalence (Table 5 ).

Table 5. Association between material and fracture types.

\begin{tabular}{ccccc}
\hline & Type III & Type IV & Type V & Fisher Test \\
\hline PMMA-Temp Basic ${ }^{\circledR}$ & $0(0 \%)$ & $11(78.6 \%)$ & $4(25.0 \%)$ & \\
Composite Resin-Lava Ultimate $^{\circledR}$ & $0(0 \%)$ & $3(21.4 \%)$ & $12(75.0 \%)$ & $p<0.001$ \\
PEEK-Tecno Med Mineral $^{\circledR}$ & $15(100 \%)$ & $0(0 \%)$ & $0(0 \%)$ & \\
\hline
\end{tabular}

All types of material obtained fracture resistances higher than functional $(>300.8 \mathrm{~N})$ and extreme $(>966.9 \mathrm{~N})$ masticatory forces, with statistically significant results, as shown in Table 6.

Table 6. Comparison of fracture resistance by material type.

\begin{tabular}{ccccc}
\hline & M & SD & Threshold 300.1 N & Threshold 966.9 N \\
\hline PMMA-Temp Basic ${ }^{\circledR}$ & 1300.4 & 97.1 & $\mathrm{t}_{(4)}=230.5(p<0.001)$ & $\mathrm{t}_{(4)}=74.5(p=0.002)$ \\
Composite Resin & 1425.9 & 49.0 & $\mathrm{t}_{(4)}=421.7(p<0.001)$ & $\mathrm{t}_{(4)}=170.6(p<0.001)$ \\
- Lava Ultimate ${ }^{\circledR}$ & 2359.5 & 50.0 & $\mathrm{t}_{(4)}=1350.4(p<0.001)$ & $\mathrm{t}_{(4)}=907.1(p<0.001)$ \\
\hline PEEK-Tecno Med Mineral ${ }^{\circledR}$ & & &
\end{tabular}


All types of fracture showed fracture resistances higher than functional $(>300.1 \mathrm{~N})$ and extreme $(>966.9 \mathrm{~N})$ masticatory forces, with statistically significant results, as shown in Table 7.

Table 7. Comparison of fracture strength by fracture type.

\begin{tabular}{ccccc}
\hline & M & SD & Threshold 300.1 N & Threshold 966.9 N \\
\hline Type III & 2359.5 & 50.0 & $\mathrm{t}_{(4)}=1350.4(p<0.001)$ & $\mathrm{t}_{(4)}=907.1(p<0.001)$ \\
Type IV & 1281.7 & 75.5 & $\mathrm{t}_{(4)}=265.4(p<0.001)$ & $\mathrm{t}_{(4)}=85.3(p<0.001)$ \\
Type V & 1434.4 & 49.0 & $\mathrm{t}_{(4)}=411.0(p<0.001)$ & $\mathrm{t}_{(4)}=167.7(p<0.001)$ \\
\hline
\end{tabular}

The crowns made with the PEEK Tecno Med Mineral ${ }^{\circledR}$ material presented the best fracture resistance (Figure 5a), followed by the crowns made with the Lava Ultimate ${ }^{\circledR}$ composite resin material (Figure $5 b$ ) and, finally, those made with the PMMA Temp Basic ${ }^{\circledR}$ material (Figure 5c).

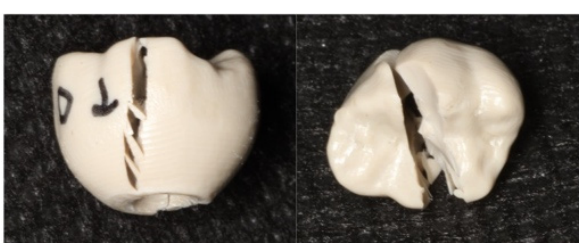

(a)

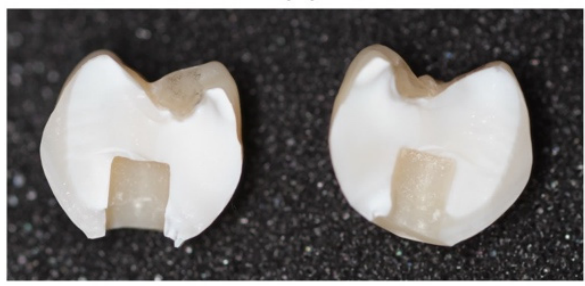

(b)

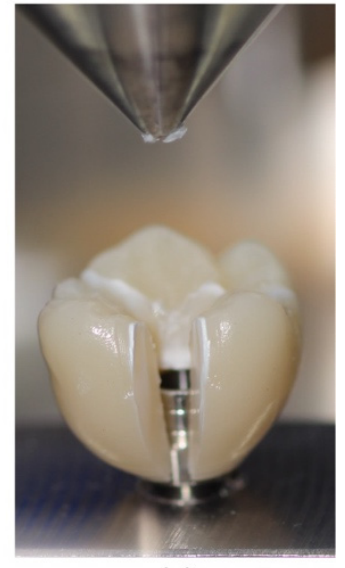

(c)

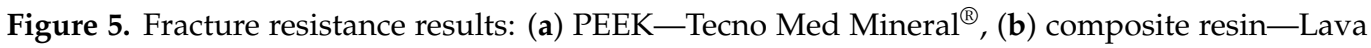
Ultimate $^{\circledR}$, and (c) PMMA-Temp Basic ${ }^{\circledR}$.

\section{Discussion}

We evaluated the fracture resistance of three materials commonly used in dentistry to create temporary crowns. Despite the limitations of laboratory fatigue tests which do not replicate the conditions existing in the oral cavity, fracture resistance values provide a good indicator of the clinical performance of materials when assessed under controlled conditions.

In order to simulate clinical conditions and after analyzing the literature-in which screw-retained ISPRs proved to be more fragile-we chose to provisionally cement the crowns [12,13]. PEEK proved to be the strongest material, followed by composite resin, while PMMA had the weakest performance. These results confirm those reported by other studies $[1-3,7,12,14]$.

As for the average strength values of each material reported in the literature, the $1300.4 \mathrm{~N}$ of PMMA was comparable to the values found by Ender et al. [15]. The composite resin, with $1425.9 \mathrm{~N}$, was comparable to the values presented by Alt et al. [7], Karaokutan et al. [1], Preis et al. [12], and Zacher et al. [16]. The PEEK value of $2359.5 \mathrm{~N}$ was similar to that reported in the review of Stawarczyk et al. [17].

The differences found in other studies can be explained by variables in the methodology, such as testing a pontic or a cantilever instead of an abutment crown, or performing fatigue tests before the final fracture test. PEEK is often tested in a hybrid form with a composite veneer, which improves its esthetics but reduces strength. 
Several studies have addressed masticatory strength, with values ranging between $190.42 \mathrm{~N}$ and $967 \mathrm{~N}[1-3,18,19]$. According to these studies, all materials tested would show resistance to normal and parafunctional masticatory function.

As for the type of fracture, all were classified as catastrophic. Type III fractures-less than half of the affected crown-were observed in PEEK samples, while type IV and V fractures-more than half of the affected crown - were the most prevalent in composite resin $\left(3 \mathrm{M}^{\circledR}\right.$ ESPE, Minnesota, USA) and PMMA samples. These results are in agreement with those presented by Karaokutan et al. [1] and Abdullah et al. [2,3].

Other studies support these results, arguing that PEEK demonstrates better marginal adaptation and fracture resistance when compared to traditional temporary materials. This material has an elastic modulus of $18 \mathrm{GPa}$ when reinforced with carbon, resembling bone tissue. The cross matrix of reinforced carbon fibers provides excellent resistance and flexural resistance, corroborating the results obtained with respect to the maximum fracture values and fracture topography. According to the authors, due to the grayish brown color of PEEK, it is not suitable for monolithic esthetic restorations on anterior teeth. Hence, a more esthetic material like composite resin should be used as a coating to get an esthetic result. Many surface conditioning methods of PEEK to improve bonding with resin composite crowns have been suggested $[8,9,13,19,20]$.

Any comparisons of results of the present study with other studies should be carried out with caution as the test parameters significantly differed from one study to the other. Furthermore, in vitro wear tests show little correlation with clinical data. In general, material loss under clinical conditions is lower than in laboratory studies. In addition, there is also a high variability of results regardless of the kind of study. Nonetheless, carrying out in vitro studies enables testing under standardized conditions, making a comparative evaluation of different materials possible $[13,19]$. For verification of the reliability of the attained wear and resistance results, clinical evaluations are required and envisaged.

\section{Conclusions}

The following conclusions were reached:

1. The PEEK Tecno Med Mineral ${ }^{\circledR}$ material was the CAD/CAM material that demonstrated the most resistant behavior to fractures, with a statistically significant difference. The PMMA Temp Basic ${ }^{\circledR}$ material obtained the lowest fracture resistance.

2. All tested materials showed fracture resistance superior to functional and extreme masticatory forces, with statistically significant results.

3. PEEK was shown to have enough strength to be considered as a long-term provisional.

Author Contributions: Conceptualization, J.M.M. and A.S.S.; methodology, P.C.B.; software, J.M.; validation, A.S.S. and J.M.M.; investigation, P.C.B.; resources, A.S.S.; data curation, C.A.; writingoriginal draft preparation, P.C.B.; writing—review and editing, J.M.M. and P.B.; visualization-A.S.S. and P.B.; supervision, J.M.M. All authors have read and agreed to the published version of the manuscript.

Funding: This research received no external funding.

Institutional Review Board Statement: Not applicable.

Informed Consent Statement: Not applicable.

Data Availability Statement: No data other than those shown in the manuscript were reported.

Acknowledgments: We are grateful for the availability and cooperation of the Department of Dental Sciences, Cooperative for Polytechnic and University Education (Cooperativa de Ensino Superior Politécnico e Universitário-CESPU), and the Advanced Institute of Research and Training in Health Sciences and Technologies (Instituto de Investigação e Formação Avançada em Ciências e Tecnologias da Saúde), Portugal.

Conflicts of Interest: The authors declare no conflict of interest. 


\section{References}

1. Karaokutan, I.; Sayin, G.; Kara, O. In vitro study of fracture strength of provisional crown materials. J. Adv. Prosthodont. 2015, 7, 27-31. [CrossRef] [PubMed]

2. Abdullah, A.O.; Pollington, S.; Liu, Y. Comparison between direct chairside and digitally fabricated temporary crowns. Dent. Mater. J. 2018, 37, 957-963. [CrossRef] [PubMed]

3. Abdullah, A.O.; Tsitrou, E.A.; Pollington, S. Comparative in vitro evaluation of CAD/CAM vs. conventional provisional crowns. J. Appl. Oral Sci. 2016, 24, 258-263. [CrossRef] [PubMed]

4. Balkenhol, M.; Ferger, P.; Mautner, M.C.; Wöstmann, B. Provisional crown and fixed partial denture materials: Mechanical properties and degree of conversion. Dent. Mater. 2007, 23, 1574-1583. [CrossRef] [PubMed]

5. Proussaefs, P. Immediate provisionalization with a CAD/CAM interim abutment and crown: A guided soft tissue healing technique. J. Prosthet. Dent. 2015, 113, 91-95. [CrossRef] [PubMed]

6. Rosentritt, M.; Hahnel, S.; Engelhardt, F.; Behr, M.; Preis, V. In vitro performance and fracture resistance of CAD/CAM-fabricated implant supported molar crowns. Clin. Oral Investig. 2017, 21, 1213-1219. [CrossRef] [PubMed]

7. Alt, V.; Hannig, M.; Wöstmann, B.; Balkenhol, M. Fracture strength of temporary fixed partial dentures: CAD/CAM versus directly fabricated restorations. Dent. Mater. 2011, 27, 339-347. [CrossRef] [PubMed]

8. Bathala, L.; Majeti, V.; Rachuri, N.; Singh, N.; Gedela, S. The Role of Polyether Ether Ketone (Peek) in Dentistry-A Review. J. Med. Life 2019, 12, 5-9. [CrossRef] [PubMed]

9. Skirbutis, G.; Dzingutè, A.; Masiliūnaitè, V.; Šulcaitè, G.; Žilinskas, J. A review of PEEK polymer's properties and its use in prosthodontics. Stomatologija 2017, 19, 19-23. [PubMed]

10. Rahmitasari, F.; Ishida, Y.; Kurahashi, K.; Matsuda, T.; Watanabe, M.; Ichikawa, T. PEEK with Reinforced Materials and Modifications for Dental Implant Applications. Dent. J. 2017, 5, 35. [CrossRef] [PubMed]

11. Najeeb, S.; Zafar, M.S.; Khurshid, Z.; Siddiqui, F. Applications of polyetheretherketone (PEEK) in oral implantology and prosthodontics. J. Prosthodont. Res. 2016, 60, 12-19. [CrossRef] [PubMed]

12. Preis, V.; Hahnel, S.; Behr, M.; Bein, L.; Rosentritt, M. In-vitro fatigue and fracture testing of CAD/CAM-materials in implantsupported molar crowns. Dent. Mater. 2017, 33, 427-433. [CrossRef] [PubMed]

13. Paratelli, A.; Perrone, G.; Ortega, R.; Gómez-Polo, M. Polyetheretherketone in Implant Prosthodontics: A Scoping Review. Int. J. Prosthodont. 2020, 33, 671-679. [CrossRef] [PubMed]

14. Vally, Z.; Sykes, L.M.; Aspeling, M.E.; van de Merwe, J.; Ballyram, R. In vitro comparison of the compressive strengths of seven different provisional crown materials. SADJ 2013, 68, 64-67. [PubMed]

15. Ender, A.; Bienz, S.; Mörmann, W.; Mehl, A.; Attin, T.; Stawarczyk, B. Marginal adaptation, fracture load and macroscopic failure mode of adhesively luted PMMA-based CAD/CAM inlays. Dent. Mater. 2016, 32, e22-e29. [CrossRef] [PubMed]

16. Zacher, J.; Bauer, R.; Strasser, T.; Rosentritt, M. Laboratory performance and fracture resistance of CAD/CAM implant-supported tooth-coloured anterior FDPs. J. Dent. 2020, 96, 103326. [CrossRef] [PubMed]

17. Stawarczyk, B.; Eichberger, M.; Uhrenbacher, J.; Wimmer, T.; Edelhoff, D.; Schmidlin, P.R. Three-unit reinforced polyetheretherketone composite FDPs: Influence of fabrication method on load-bearing capacity and failure types. Dent. Mater. J. 2015, 34, 7-12. [CrossRef] [PubMed]

18. Varga, S.; Spalj, S.; Lapter Varga, M.; Anic Milosevic, S.; Mestrovic, S.; Slaj, M. Maximum voluntary molar bite force in subjects with normal occlusion. Eur. J. Orthod. 2011, 33, 427-433. [CrossRef] [PubMed]

19. Cekic-Nagas, I.; Egilmez, F.; Ergun, G.; Vallittu, P.K.; Lassila, L.V.J. Load-bearing capacity of novel resin-based fixed dental prosthesis materials. Dent. Mater. J. 2018, 37, 49-58. [CrossRef] [PubMed]

20. Papathanasiou, I.; Kamposiora, P.; Papavasiliou, G.; Ferrari, M. The use of PEEK in digital prosthodontics: A narrative review. BMC 2020, 20, 217. [CrossRef] [PubMed] 